\title{
Understand Your Family Firm's Core Strengths and Weaknesses
}

\author{
Thomas Zellweger (University of St. Gallen)
}

KEYWORDS: Management, Leadership, Family Business, human resources.

It's been said that, "Once you have seen one family firm, you have seen just one family firm." While it's popular to say that every family firm is unique, as a researcher I take issue with the idea that family businesses don't share common strengths and challenges.

Family firms come in many different shapes, sizes and generations. However, looking into the wide and growing family business literature, I would say that family firms typically vary within five dimensions. And assessing how a family firm scores in these five dimensions will allow us to make fairly solid predictions about the typical strengths and weaknesses that this firm should encounter. To help family businesses have a better look at where they stand, I have developed an online tool called the Family Business Navigator.

To access the navigator, visit www.familybusinessnavigator.com (http://www.familybusinessnavigator.com)

(http://www.familybusinessnavigator.com) . Your selfassessment will lead you through the five dimensions in which family firms typically vary: (1) amount of family control, (2) complexity of family control, (3) business setup, (4) philosophy of control, and (5) stage of control.

Your self-assessment will result in a spider diagram like the one below, and an indication of the typical strengths and weaknesses depending on how you score in the five dimensions.

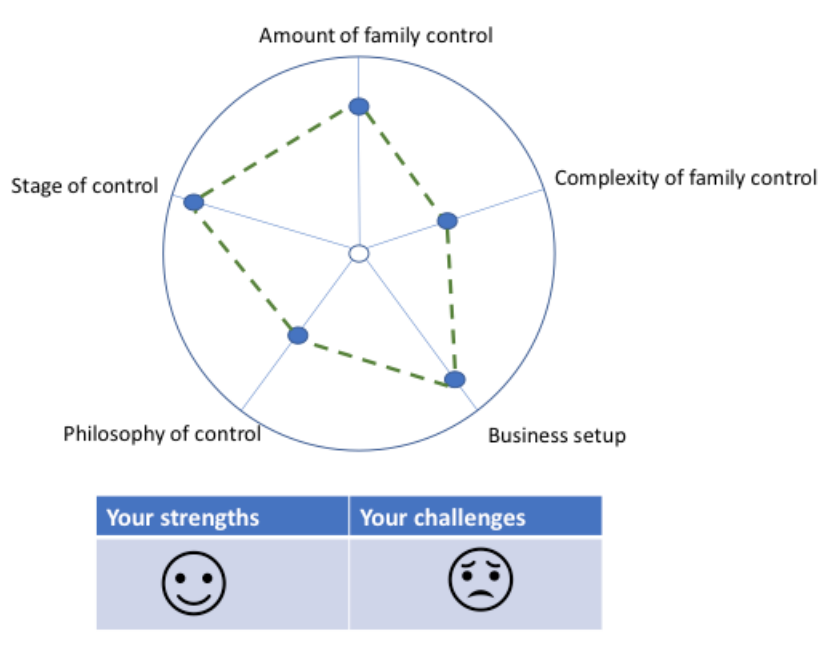

The five dimensions are briefly explained below:

\section{Amount of control in family hands}

Finance and management research has found that the amount of control an owner, such as a family, has over a company will determine how effectively the firm will be run. Tight control most often means more efficiency and closer oversight. Opening up control allows the firm to tap non-family resources and talent but also risks conflict over goals and interests between family and nonfamily stakeholders. We can assess the amount of control in family hands at the level of ownership, management and the board.

\section{Complexity of family control}

Family firms also vary in how they divide control among family members. For instance, strategic decisionmaking will be different depending on whether one person or four people manage the company. We've seen three very distinct types of management within family firms -- the owner-managed firm, siblingpartnership and the family enterprise -- all with varying
Copyright @ 2020 The Authors. Entrepreneur \& Innovation Exchange is published at EIX.org. This is an open access article under the terms of the Creative Commons Attribution-NoDerivs License, which permits use and distribution in any medium, provided the original work is properly cited and no modifications or adaptations are made. View EIX.org Authorship Terms at https://eix.org/terms
FamilyBusiness 
levels of complexity. As complexity increases, it changes the firm's relational dynamics and need for governance.

\section{Business setup}

Some family enterprises are more complex than others -- for example, one family may run a single firm while another may run several; and some business operations are more diversified than others. The degree of business complexity has a massive impact on issues such as risk management, current and future growth opportunities, required skills at the family level to run the business(es), and career opportunities for family members.

\section{Philosophy of control}

This dimension, which has been heavily researched in the past decade, deals with a family enterprise's nonfinancial priorities: its socio-emotional goals. Each family balances financial and non-financial goals differently. Some care more about the family reputation than anything else; other firms may prioritize engagement with the local community and supporting important causes. These socio-emotional goals can build a good name for the family and good will from the community, and support for the family firm, but they can also bias the family and prevent them from making economically rational decisions.

\section{Stage of control}

Family firms are different from other closely-held firms because they typically wish to preserve family control over the business for the next family generation. But over time this wish may waver, or even disappear altogether. This will have an important impact on the firm's succession plans and whether they include the next generation or outsiders. Also, we know that foundercontrolled firms differ from later-stage family firms on several levels -- for example the degree of stewardship that owners feel towards the firm, and the willingness to take risks and remain entrepreneurial.

\section{The Family Business Navigator}

Developing an understanding about how your firm is positioned along these five dimensions will give you perspective on the typical strengths and challenges you may share with other family firms. Family businesses, consultants and teachers can access the tool on www.familybusinessnavigator.com

(http://www.familybusinessnavigator.com) (http://www.familybusinessnavigator.com) . I hope it will help you! If you have any suggestions to improve it, please email me at thomas.zellweger@unisg.ch (mailto:thomas.zellweger@unisg.ch)

\section{References}

Zellweger, Thomas, Managing the Family Business: Theory \& Practice, Edward Elgar, 2017, Chapter 2.

\section{Learn More}

Unlocking the Innovation Potential of Family Firms: An Assessment Tool (https://familybusiness.org/content/unlocking-theinnovation-potential-of-family-firms-an-assessment)

Outside Leadership Can Save the Family Business (https://familybusiness.org/content/Outside-leadershipcan-save-the-family-business)

Choosing a Board of Directors for a Family Business (https://familybusiness.org/content/choosing-a-board-ofdirectors-for-a-family-busin) 